\title{
Pengaruh Penambahan Abu Sekam Padi Terhadap Peningkatan Kualitas Minyak Mandar
}

\section{[The Effect of Rice Husk Ash Addition on The Increasing of Mandar Coconut Oil Quality]}

\author{
Musafira $^{1^{\star}}$, Dzulkifli $^{2}$, Hikmah $^{1}$, Nizar $^{3}$ \\ ${ }^{1}$ Fakultas MIPA, Universitas Sulawesi Barat \\ ${ }^{2}$ Fakultas Teknik, Universitas Sulawesi Barat \\ ${ }^{3}$ Fakultas Pertanian dan Kehutanan, Universitas Sulawesi Barat
}

\begin{abstract}
Mandar coconut oil is one of the coconut processed products, which has become superior product in West Sulawesi especially in Majene regency. Unfortunately, the Mandar coconut oil can't be used more than a month because the water content and free fatty acid content of the oil have exceeded the maximum standard of SNI, so it can adversely affect on health. On the other hand, the existence of rice husk in Indonesia itself especially in West Sulawesi has not received attention and is limited to a few needs such as for ash or livestock feed, and the rest is thrown away. This research aims to determine the effect of rice husk ash addition on the increasing of Mandar coconut oil quality. Completely randomized design was used in this research with 6 rice husk ash concentration variation levels i.e. $0 \%, 5 \%, 10 \%, 15 \%, 20 \%$ and $25 \%$. The result shows that the addition of rice husk ash with $10 \%$ to $25 \%$ can reduce the water content of the oil until the quality standard of SNI is full filled. The highest reduction of water content was reached with $25 \%$ of rice husk ash concentration with $81 \%$ of reduction percentage. While, the addition of rice husk ash with $15 \%$ concentration can reduce the free fatty acid content of Mandar coconut oil until $32 \%$.
\end{abstract}

Keywords: Rice husk ash, mandar coconut oil,water content, free fatty acid

Abstrak. Minyak kelapa Mandar merupakan salah satu produk olahan dari kelapa yang menjadi salah satu produk unggulan di Sulawesi Barat khususnya di daerah Majene. Sayangnya, penggunaan minyak kelapa Mandar yang sudah tersimpan selama lebih 1 bulan memiliki kadar air dan kadar asam lemak bebas yang melebihi persyaratan maksimal yang ditetapkan oleh Standar Nasional Indonesia (SNI), sehingga dapat berdampak buruk bagi kesehatan. Disisi lain, keberadaan sekam padi di Indonesia khususnya di Sulawesi Barat belum mendapatkan perhatian dan penggunaannya masih terbatas untuk beberapa keperluan saja seperti untuk abu gosok atau pakan ternak, sedangkan sisanya dibuang. Penelitian ini bertujuan untuk menentukan pengaruh penambahan abu sekam padi terhadap peningkatan kualitas minyak kelapa Mandar. Penelitian ini menggunakan rancangan acak lengkap dengan menggunakan 6 level variasi konsentrasi abu sekam padi yakni 0\%, 5\%, 10\%, 15\%, 20\% dan 25\%. Hasil penelitian menunjukkan bahwa penambahan abu sekam padi mulai dari $10 \%$ hingga $25 \%$ mampu menurunkan kadar air minyak kelapa Mandar hingga mencapai standar mutu yang dipersyaratkan oleh SNI. Penambahan abu sekam padi dengan konsentrasi $25 \%$ menghasilkan penurunan kadar air paling tinggi yakni sebesar $81 \%$. Sedangkan, hasil dari pengaruh penambahan abu sekam padi terhadap kadar asam lemak bebas dari minyak kelapa Mandar diperoleh persentase penurunan asam lemak bebas yang terbesar diperoleh pada penggunaan abu sekam padi dengan konsentrasi $15 \%$, dengan persentase penurunannya sebesar $32 \%$.

Kata kunci: Abu sekam padi, minyak kelapa mandar, kadar air, kadar asam lemak bebas

Diterima: 6 April 2021, Disetujui: 18 April 2021

Sitasi: Musafira., Dzulkifli., Hikmah., \& Nizar. (2021). Pengaruh Penambahan Abu Sekam Padi Terhadap Peningkatan Kualitas Minyak Mandar. KOVALEN: Jurnal Riset Kimia, 7(1): 83-88.

\footnotetext{
* Corresponding author

E-mail: musafira@unsulbar.ac.id
} 


\section{LATAR BELAKANG}

Minyak kelapa Mandar merupakan salah satu produk olahan dari kelapa yang merupakan produk unggulan di Sulawesi Barat khususnya di daerah Majene. Minyak kelapa Mandar dibuat secara tradisional dengan bahan baku berasal dari kelapa tua yang diparut dan diperas santannya lalu dipanaskan selama 4 jam. Minyak kelapa yang dihasilkan dari proses tersebut memiliki rasa gurih dan aroma yang spesifik. Hal tersebut menyebabkan minyak kelapa Mandar masih diproduksi hingga saat ini.

Berdasarkan hasil penelitian Musafira et al. (2020), penggunaan minyak kelapa Mandar yang sudah tersimpan selama lebih 1 bulan memiliki kadar air $(0,84 \%)$ dan kadar asam lemak bebas $(2,65 \%)$ yang tinggi dan melebihi persyaratan maksimal yang ditetapkan oleh pemerintah melalui Standar Nasional Indonesia (SNI) 01-3741-2002 tentang syarat mutu minyak goreng kelapa (Tabel 1). Kerusakan pada minyak dapat terjadi selama penyimpanan. Minyak yang disimpan dalam waktu tertentu dapat menyebabkan ikatan trigliserida pada minyak terputus dan membentuk gliserol dan asam lemak bebas (Gambar 1). Disamping itu, adanya kandungan asam lemak tidak jenuh pada minyak kelapa sekitar 5.0-11.5\% memungkinkan terjadinya reaksi oksidasi pada asam lemak tidak jenuh dalam minyak yang menghasilkan gas $\mathrm{CO}_{2}$, asam volatile, aldehid dan sejumlah molekul air (Ketaren, 1986; Sirait et al., 1996).

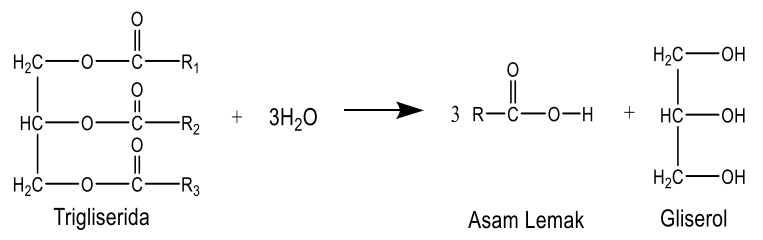

Gambar 1. Reaksi Hidrolisis Trigliserida pada Minyak (Irawan et al., 2013).
Menurut Fanani \& Ningsih (2018); Irawan et al. (2013); dan Suroso (2013), minyak kelapa dapat mudah rusak apabila kadar asam lemak bebas dan kadar air tinggi, sehingga dapat menyebabkan gangguan kesehatan bila dikonsumsi, seperti diare, kanker, penyempitan pembuluh darah arteri, dan bahkan dapat menyebabkan kerusakan pada hati. Perlu adanya pengembangan teknik pengolahan minyak kelapa, khusus minayak kelapa Mandar untuk menurunkan kadar air dan kadar asam lemak bebas.

Tabel 1. Standar mutu minyak goreng kelapa berdasarkan SNI 01-3741-2002

\begin{tabular}{llll}
\hline No. & Kriteria Uji & $\begin{array}{c}\text { Persyaratan } \\
\text { Mutu I }\end{array}$ & $\begin{array}{c}\text { Persyaratan } \\
\text { Mutu II }\end{array}$ \\
\hline 1. & Bau & Normal & Normal \\
2. & Rasa & Normal & Normal \\
3. & Warna & Muda jernih & Muda jernih \\
4. & Kadar Air & Max. 0,1\% & Max. 0,3\% \\
5. & Asam Lemak & Max. 2\% & Max. 2\% \\
& Bebas & & \\
\hline
\end{tabular}

Sumber : Nasruddin (2011)

Proctor et al. (1995) dalam Irwan et al. (2019), menyatakan bahwa abu sekam padi dapat mengabsorbsi pigmen selama pengolahan minyak, disamping itu dapat menyerap asam lemak bebas secara signifikan. Abu sekam padi merupakan hasil dari proses pembakaran sekam padi. Abu sekam padi biasanya dimanfaatkan sebagai abu gosok atau dibuang begitu saja (Nurwendi, 2012). Abu sekam padi umumnya mengandung beberapa komponen kimia seperti yang terlihat pada Tabel 2. Penggunaan abu sekam padi sebagai media penyerap (adsorben) dikarenakan abu sekam padi merupakan material yang kandungan $\mathrm{SiO}_{2}$ yang cukup tinggi dan memiliki pori serta situs aktif, yaitu Si$\mathrm{OH}$ dan Si-O-Si (Setyaningtyas, 2005 dalam Nurhasni et al., 2014). 
Tabel 2. Komponen kimia abu sekam padi

\begin{tabular}{cc}
\hline Komponen Kimia & (\% berat) \\
\hline $\mathrm{SiO}_{2}$ & 72.28 \\
$\mathrm{Al}_{2} \mathrm{O}_{3}$ & 0.37 \\
$\mathrm{Fe}_{2} \mathrm{O}_{3}$ & 0.32 \\
$\mathrm{CaO}$ & 0.65
\end{tabular}

Sumber: Bakri (2009)

Saat ini penelitian terkait penggunaan abu sekam padi pada minyak kelapa Mandar belum dilakukan. Melimpahnya sekam padi yang mudah diperoleh dari limbah pertanian serta dapat dijadikan abu sekam, serta besarnya kemampuan abu sekam padi dalam menyerap asam lemak bebas maka penelitian tentang pengaruh penambahan abu sekam padi terhadap peningkatan kualitas minyak kelapa Mandar perlu dilakukan. Hasil penelitian yang dilakukan bertujuan untuk mendapatkan konsentrasi abu sekam padi yang tepat dalam menurunkan kadar air dan kadar asam lemak bebas minyak kelapa Mandar.

\section{METODE PENELITIAN}

\section{Bahan dan Peralatan}

Bahan penelitian meliputi minyak goreng dari kelapa (minyak Mandar) yang diperoleh dari salah satu pedagang minyak goreng di Kampung Tulu, Labuang Kecamatan Banggae Timur Kabupaten Majene, abu sekam padi, $\mathrm{NaOH}$ 0,1 N, alkohol 95\% panas, akuades, indikator pp.

Peralatan penelitian meliputi: sentrifus, timbangan analitik, oven, desikator, pengaduk magnetik, cawan porselen, buret, klem dan statif.

\section{Prosedur Kerja}

Abu sekam padi berukuran 60 mesh dipanaskan dalam oven pada suhu $120^{\circ} \mathrm{C}$ selama 2 jam untuk menghilangkan kadar airnya, kemudian dikemas dalam wadah tertutup kedap udara. Selanjutnya, minyak kelapa Mandar ditambahkan abu sekam padi dengan taraf konsentrasi $0 \%, 5 \%, 10 \%, 15 \%$, $20 \%$ dan $25 \%$, lalu diaduk dengan pengaduk magnetik kecepatan $300 \mathrm{rpm}$ selama 1 jam. Setelah itu, minyak kelapa dipisahkan dari abu sekam dengan menggunakan sentrifuge yang kecepatannya 1000 rpm (Irwan et al., 2019). Minyak kelapa yang diperoleh dari hasil sentrifugasi, selanjutnya dianalisis kadar air dan kadar asam lemak bebas.

Analisis kadar air dilakukan dengan menggunakan prosedur dari Fanani \& Ningsih (2018), sedangkan analisis kadar asam lemak bebas menggunakan prosedur AOAC (1999).

\section{HASIL DAN PEMBAHASAN}

\section{Kadar Air}

Hasil yang diperoleh menunjukkan bahwa semakin tinggi konsentrasi abu sekam padi yang ditambahkan ke dalam minyak kelapa Mandar, maka kadar air dari minyak akansemakin berkurang (Gambar 1). Hal ini menunjukkan bahwa penambahan adsorben abu sekam padi pada minyak kelapa Mandar memiliki pengaruh terhadap kadar air minyak. Kemampuan abu sekam padi dalam mengurangi kadar air minyak telah dijelaskan sebelumnya oleh Sulo et al. (2019), gugus $\mathrm{SiO}_{2}$ pada abu sekam padi memiliki sifat hidrofilik sehingga sangat berkontribusi dalam proses pengikatan air. Proses pengikatan air pada gugus $\mathrm{SiO}_{2}$ tersebut diperkirakan melalui pembentukan ikatan hidrogen. Proses adsorpsi secara umum didefinisikan sebagaimana pada persamaan reaksi berikut:

$$
X+S \leftrightarrow X S
$$

$\mathrm{X}$ merupakan adsorbat, $\mathrm{S}$ sebagai permukaan adsorben, dan XS sebagai molekul $X$ yang 
terjerap di permukaan adsorben (Castelan, 1983).

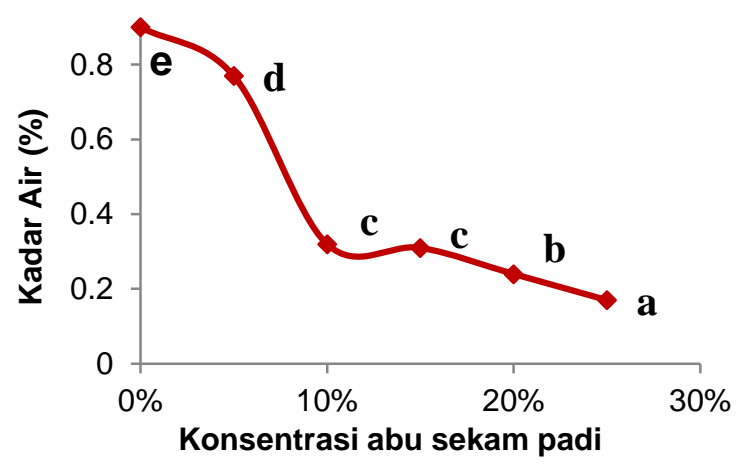

Gambar 1. Kadar air minyak kelapa Mandar pada beberapa variasi konsentrasi abu sekam padi

Kadar air minyak yang dihasilkan dengan penambahan abu sekam padi dengan konsentrasi $5-25 \%$ berkisar $0,77-0,17 \%$. Pada penambahan abu sekam padi dengan konsentrasi mulai $10 \%$ hingga $20 \%$ diperoleh kadar air minyak yang sudah memenuhi persyaratan mutu II dari SNI 0137412002 yakni maksimal $\quad 0,30 \%$. Sedangkan pada penambahan abu sekam padi dengan konsentrasi $25 \%$ diperoleh kadar air minyak yang memenuhi persyaratan mutu I dari SNI 0137412002 yakni maksimal 0,10\%. (Nasruddin, 2011). Hal ini menunjukkan bahwa penambahan abu sekam padi mulai dari $10 \%$ hingga $25 \%$ pada dasarnya sudah memenuhi persyaratan SNI. Penambahan abu sekam padi dengan konsentrasi 25\% menghasilkan penurunan kadar air paling tinggi yakni sebesar $81 \%$. Hasil ini didukung dengan hasil analisis ragam (Gambar 1), yaitu penambahan abu sekam padi berpengaruh nyata terhadap penurunan kadar air minyak dan penambahan abu sekam padi dengan konsentrasi 25\% memberikan pengaruh yang sangat nyata.

\section{Kadar Asam Lemak Bebas}

Kadar asam lemak bebas (free fatty acid) menjadi salah satu parameter penting pada kualitas minyak.Kadar asam lemak bebas yang semakin tinggi pada minyak akan menurunkan kualitas minyak tersebut (Fanani \& Ningsih, 2018). Hasil penelitian menunjukkan bahwa sebelum penambahan abu sekam padi, kadar asam lemak bebas yang dihasilkan sebesar $0,43 \%$. Pada penambahan abu sekam padi dengan konsentrasi $5 \%$ dihasilkan kadar asam lemak bebas sebesar $0,36 \%$ dengan persentase penurunan kadar asam lemak bebas sebesar $16 \%$ dari kadar awal sebelum penambahan abu sekam padi. Kadar asam lemak bebas semakin menurun seiring dengan meningkatnya konsentrasi abu sekam padi yang ditambahkan (Gambar 2).

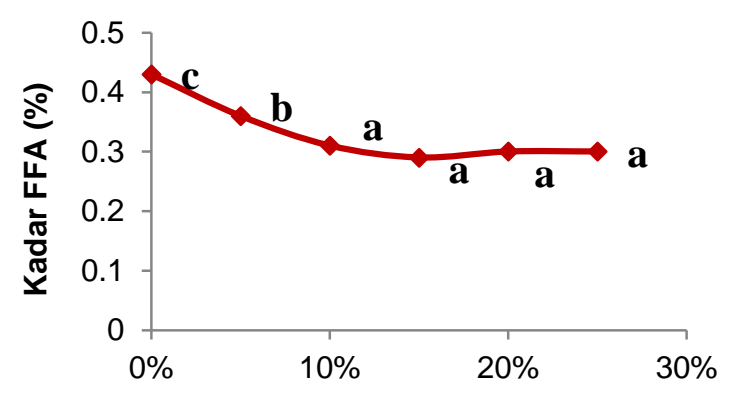

Konsentrasi abu sekam padi

Gambar 2. Kadar asam lemak bebas minyakkelapa Mandar pada beberapa variasi konsentrasi abusekam padi

Penurunan asam lemak bebas yang terbesar diperoleh pada penggunaan abu sekam padi dengan konsentrasi $15 \%, 20 \%$ dan $25 \%$ dengan persentase penurunannya berkisar 30\%. Hal ini disebabkan karena selain merupakan material berpori, abu sekam padi mengandung situs aktif yakni $\mathrm{Si}-\mathrm{OH}$ dan Si-OSi yang diprediksi memiliki peranan yang besar dalam proses penyerapan melalui ikatan yang terjadi antara oksigen dari gugus karbonil asam lemak bebas dengan hydrogen dari silanol pada antar muka silika abu sekam padi membentuk ikatan hydrogen (Istiningrum et al., 
2017; Setyaningtyas, 2005 dalam Nurhasni et al., 2014; Topallar \& Bayrak, 1999).

Analisis ragam menunjukkan bahwa konsentrasi abu sekam padi berpengaruh sangat nyata terhadap penurunan kadar asam lemak bebas minyak kelapa Mandar. (Gambar 2) Perlakuan kontrol (konsentrasi abu sekam padi $0 \%$ ) memilki kadar asam lemak bebas tertinggi yang berbeda nyata dengan taraf konsentrasi lainnya, sedangkan kadar asam lemak bebas terendah didapatkan pada penambahan abu sekam padi $15 \%$ dan berbeda tidak nyata dengan konsentrasi 10\%, $20 \%$, dan $25 \%$, tetapi berbeda nyata dengan perlakuan konsentrasi $0 \%$ dan $5 \%$. Hal tersebut menunjukkan bahwa konsentrasi 10\% hingga $25 \%$ memberikan pengaruh yang sama terhadap penurunan kadar asam lemak bebas. Pada saat situs aktif pada adsorben telah jenu, maka penambahan konsentrasi adsorben yang lebih tinggi tidak akan mempengaruhi jumlah zat yang teradsorbsi (Fasya \& Fadila, 2017).

\section{KESIMPULAN}

Abu sekam padi pada penambahan $10 \%$ hingga 25\% mampu menurunkan kadar air minyak kelapa Mandar hingga mencapai standar mutu yang dipersyaratkan oleh SNI. Penurunan kadar air tertinggi didapatkan pada penambahan abu sekam padi $25 \%$, yaitu $81 \%$. Penurunan asam lemak bebas tertinggi terjadi pada penambahan abu sekam padi dengan konsentrasi $15 \%$, yaitu hingga $32 \%$.

\section{DAFTAR PUSTAKA}

AOAC. (1999). Official Methods of Analysis of the Association of Official Analytical ChemistInternational. 16thed. AOAC Inc.

Bakri. (2009). Komponen Kimia Dan Fisik Abu Sekam Padi Sebagai SCM Untuk Pembuatan Komposit Semen. Perennial, $5(1)$. https://doi.org/10.24259/perennial.v5i1.1 84

Castelan, G. W. (1983). Physical Chemistry. Addison publishing Company, London.

Fanani, N., \& Ningsih, E. (2018). Analisis Kualitas Minyak Goreng Habis Pakai yang Digunakan oleh Pedagang Penyetan di Daerah Rungkut Surabaya Ditinjau dari Kadar Air dan Kadar Asam Lemak Bebas (ALB). Jurnal IPTEK, 22(2), $\quad$ 59-66. https://doi.org/10.31284/j.iptek.2018.v22 i2.436

Fasya, A. Z., \& Fadila, N. (2017). Pemanfaatan Arang Sekam Padi Sebagai Adsorben Guna Mengurangi Limbah Cr. [Laporan Tugas Akhir]. Departemen Teknik Kimia Industri Fakultas Vokasi Institut Teknologi Sepuluh Nopember.

Irawan, C., Awalia, T. N., \& W.p.h, S. U. (2013). Pengurangan Kadar Asam Lemak Bebas (Free Fatty Acid) Dan Warna Dari Minyak Goreng Bekas Dengan Proses Adsorpsi Menggunakan Campuran Serabut Kelapa Dan Sekam Padi. Konversi, 2(2), 28-32. https://doi.org/10.20527/k.v2i2.82

Irwan, I., Alam, N., \& Asrawaty, A. (2019). Konsentrasi Abu Sekam Padi Terhadap Kualitas Minyak Kopra. Jurnal Pengolahan Pangan, 4(1), 9-15. https://doi.org/10.31970/pangan.v4i1.21

Istiningrum, R. B., E.a, P., L. A., S., \& D, N. (2017). Pemanfaatan Abu Sekam Padi Untuk Pemurnian Bahan Baku Dan Produk Biodiesel Dari Minyak Jelantah. JST (Jurnal Sains dan Teknologi), 6(1), Article 1. https://doi.org/10.23887/jstundiksha.v6i1.9440

Ketaren. (1986). Minyak dan Lemak Pangan. Universitas Indonesia Prees.

Musafira, Dzulkifli, Fardinah, \& Nizar. (2020). Pengaruh Kadar Air dan Kadar Asam Lemak Bebas Terhadap Masa Simpan Minyak Kelapa Mandar: KOVALEN: Jurnal Riset Kimia, 6(3), 224-229. https://doi.org/10.22487/kovalen.2020.v 6.i3.15344

Nasruddin. (2011). Studi kualitas minyak goreng dari kelapa (Cocos nucifera L.) melalui proses sterilisasi dan pengepresan. Jurnal Dinamika Penelitian Industri, 22(1), 9-18. https://doi.org/10.28959/jdpi.v22i1.534 
Nurhasni, N., Hendrawati, H., \& Saniyyah, N. (2014). Sekam Padi untuk Menyerap Ion Logam Tembaga dan Timbal dalam Air Limbah. Jurnal Kimia Valensi, 4(1), Article https://doi.org/10.15408/jkv.v4i1.1074

Nurwendi, A. F. (2012). Studi Kemampuan Adsorpsi Abu Sekam Padi untuk Mengolah Limbah Stronsium. Teknofisika, 1(1), 12-19.

Sirait, S., Widiyanti, S., \& Bunasor, T. (1996). Pengaruh Metode Ekstraksi Dan Lama Penyimpanan Terhadap Mutu Minyak Kelapa Kasar. Warta IHP, 13(1-2).

Sulo, L. mariance, Khairuddin, \& Ruslan. (2019). KEmampuan Adsorbsi Abu Sekam Padi Terhadap Air Dan Asam Lemak Bebas Virgin Coconut Oil (VCO) Dalam Kolom Adsorbsi. KOVALEN: Jurnal Riset Kimia, 5(2), 121-131. https://doi.org/10.22487/kovalen.2019.v 5.i2.10115

Suroso, A. S. (2013). Kualitas Minyak Goreng Habis Pakai Ditinjau dari Bilangan Peroksida, Bilangan Asam dan Kadar Air. Jurnal Kefarmasian Indonesia, 3(2), 77-88.

https://doi.org/10.22435/jki.v3i2.4058.77 $-88$

Topallar, H., \& Bayrak, Y. (1999). Investigation of adsorption isotherms of myristic, palmitic and stearic acids on rice hull ash. Turkish Journal of Chemistry, 23(2), 193-198. 